\title{
The 10-year outcomes of the ASR XL Acetabular System: a single-center experience from China
}

\author{
Guojun Jin ${ }^{1,2 \dagger}$, Jisheng Ran ${ }^{2 \dagger}$, Weiping Chen², Yan Xiong ${ }^{2}$, Jiapeng Bao ${ }^{2}$ and Lidong $\mathrm{Wu}^{2^{*}}$
}

\begin{abstract}
Background: The revision rate of articular surface replacement (ASR) implants continues to rise in China because of metal debris. However, there are few reports on the clinical results of ASR implants with prolonged follow-up time in China. This study investigated the clinical outcomes and the risk factors of revision surgery in patients with ASR implants.
\end{abstract}

Methods: In total, 74 patients (74 hips) who underwent primary total hip arthroplasty (THA) with ASR implants over the past 4 to 10 years were retrospectively analyzed. Relevant clinical, radiographic, and biochemical data were examined.

Results: The average follow-up time was 88.46 (range 23-114) months, and the ASR implants of 18 hips (24.3\%) were revised. Patients who received revision surgery had worse joint function with significantly lower Harris Hip Score and Western Ontario and McMaster Universities index than non-revision patients (61.11 \pm 6.68 vs $85.30 \pm 9.16$, $p<0.001 ; 61.00 \pm 3.83$ vs $79.04 \pm 14.49, p<0.001$; respectively). Higher acetabular abduction angle and serum Co and $\mathrm{Cr}$ concentration were significantly relevant to worse joint function as measured by HSS ( $p=0.018,0.009,0.043$, respectively). ROC curve analysis was applied to categorize the optimal cutoff values of acetabular abduction angle and serum $\mathrm{Cr}$ and Co concentration for revision surgery, which were settled as $47.80^{\circ}, 98.44 \mu \mathrm{g} / \mathrm{L}$, and $6.95 \mu \mathrm{g} / \mathrm{L}$, respectively. Overall survival of the prostheses with high acetabular abduction angle $\left(>47.80^{\circ}, \mathrm{HR}=70.145,95 \% \mathrm{Cl}\right.$ 1.558-3158.213, $p=0.029)$, high serum Cr concentration (98.44 $\mu \mathrm{g} / \mathrm{L}, \mathrm{HR}=58.956,95 \% \mathrm{Cl} 1.294-2685.203, p=0.036)$, and high serum Co concentration (>6.95 $\mu \mathrm{g} / \mathrm{L}, \mathrm{HR}=179.511,95 \% \mathrm{Cl} 2.360-13656.941, p=0.019)$ decreased significantly than the lower groups.

Conclusions: Evaluation of the DePuy ASR XL articulation demonstrated increased rates of revision following a longer follow-up period. High acetabular abduction angle and serum $\mathrm{Cr}$ and $\mathrm{Co}$ concentration correlated with worse clinical outcomes and high revision rate. Therefore, we advocate that patients with DePuy ASR XL implants be followed up more closely than those with other implants, especially with high acetabular abduction angle and serum $\mathrm{Cr}$ or Co concentration.

Keywords: Metal-on-metal, Total hip arthroplasty, Metal ion, Survivorship analysis

\footnotetext{
* Correspondence: wulidong@zju.edu.cn

The English in this document has been checked by at least two professional editors, both native speakers of English. For a certificate, please see: http:// www.textcheck.com/certificate/XSuqXD

${ }^{\dagger}$ Guojun Jin and Jisheng Ran contributed equally to this work.

${ }^{2}$ Department of Orthopedic Surgery, The Second Affiliated Hospital, Zhejiang University School of Medicine, 88th Jie Fang Road, Hangzhou 310009, China Full list of author information is available at the end of the article
}

(c) The Author(s). 2019 Open Access This article is distributed under the terms of the Creative Commons Attribution 4.0 International License (http://creativecommons.org/licenses/by/4.0/), which permits unrestricted use, distribution, and reproduction in any medium, provided you give appropriate credit to the original author(s) and the source, provide a link to the Creative Commons license, and indicate if changes were made. The Creative Commons Public Domain Dedication waiver (http://creativecommons.org/publicdomain/zero/1.0/) applies to the data made available in this article, unless otherwise stated. 


\section{Introduction}

Total hip arthroplasty (THA) is currently one of the most commonly performed and successful surgeries in China, for which can restore function, alleviate pain, and greatly improve the quality of life of patients with hip problems. However, implant failure is common due to early wear and localized osteolysis [1]. Metal-on-metal (MoM) THA has emerged as an attractive alternative bearing surface, because of hard-on-hard bearing surfaces yielding a superior wear profile, preventing osteolysis, and improving implant longevity $[2,3]$. Furthermore, MoM bearing allows for the implantation of femoral heads with larger diameters, thus increasing the head-to-neck ratio and jump height and theoretically improving the range of motion (ROM) while decreasing the risk of dislocation [4].

ASR XL is a MoM bearing surface implant that is widely used in China. The reasons for revision differ from those of other prostheses. The ASR acetabular component, although stable [5], is subject to more wear than other resurfacing devices and higher concentrations of cobalt (Co) and chromium ( $\mathrm{Cr}$ ) ions in patients' blood and urine [6-8]. The incidence of pseudotumors after MoM arthroplasty is reported to be as high as 39 to $59 \%[9,10]$.

The revision rate of this ASR XL articulation continues to rise in China. Concerns over the early performance of this design led our institution to stop using this device after less than 4 years. The present situation is in certain center which illuminates the usage of DePuy ASR articulation; however, their follow-up time is only 2 to 5 years. Moreover, as to this series report, in China, it has not yet referred.

From July 2006 to January 2010, we performed more than 100 surgeries using the ASR XL (DePuy, Warsaw, IN, USA) in our institution. We took a retrospective review of our mid-term clinical experiences with 74 consecutive DePuy ASR XL THA procedures performed by three senior orthopedic surgeons. Our study aimed to assess the implant design's performance with respect to the following: (1) the demographic characteristics of patients who underwent MoM THA, (2) the relationship between blood metal ion levels and rate of early clinical failure, (3) the cumulative survival probability at the final follow-up, and (4) the risk factors of the revision surgery.

\section{Materials and methods}

\section{Patients}

We prospectively followed 98 patients (101 hips) after second-generation MoM for primary THAs from July 2006 to January 2010. Patient data are maintained in a database that includes observations from clinical examinations, radiological data, blood $\mathrm{Co}$ and $\mathrm{Cr}$ ion levels, and cross-sectional imaging. The data were analyzed retrospectively. Prior to the initiation of this study, approval was obtained from the local ethics committee and each patient provided informed consent.

In total, 25 hips were lost to follow-up; one patient was lost to high paraplegia (cervical spine fracture), and one died of causes unrelated to surgery; five patients received an ASR HR in one hip and an ASR THR in the other hip and were excluded from the study; and the rest 18 patients were out of contact during the follow-up. Overall, 74 prostheses were analyzed for Kaplan-Meier survivorship using clinical and radiographic outcome measures. Seventy-four patients (74 hips) had complete metal ion data for serial outcome measurements. This subset had concomitant clinical and radiographic parameters to substantiate our metal ion data.

\section{Surgery}

All surgeries were performed by three senior surgeons. A posterolateral approach with detachment of the short external rotators was utilized in all procedures. The acetabulum was prepared by under-reaming by $1 \mathrm{~mm}$. The ASR acetabular component is a CoCrMo alloy one-piece cup with proprietary porous coating. The outer surface of the cup consists of this porous coating with the addition of hydroxyapatite coating.

\section{Clinical evaluation}

The Harris Hip Score (HHS) was determined at each follow-up visit by one physician Dr. Jisheng Ran. The ROM was calculated as part of the HHS. The Western Ontario and McMaster Universities (WOMAC) index were also determined based on a questionnaire.

\section{Biochemical evaluation}

Venous whole blood samples were obtained to determine $\mathrm{Co}$ and $\mathrm{Cr}$ levels. Blood was initially sent to the Analysis and Testing Center of Zhejiang University. The Analysis and Testing Center utilized an octopole reaction system (ORS) inductively coupled plasma mass spectrometer (ICPMS) to measure the whole blood metal ion levels. The ORS-ICPMS method has been previously described by Pei [11].

\section{Radiological evaluation}

Standardized anteroposterior (AP) and cross-table lateral radiographs of the pelvis and hip were assessed. All AP radiographs were taken with the legs in $15^{\circ}$ internal rotation. The cup inclination angle in the frontal plane was measured against a horizontal reference line drawn along Kohler's teardrop figures.

\section{Statistical analysis}

Kaplan-Meier survivorship analysis was performed to determine the survival rates in the THA groups. Although the survival rates were not statistically compared, 
the differences between the revised and non-revised groups were compared. Normally distributed continuous variables (e.g., age, cup inclination, and femoral head diameter) were compared by independent $t$ tests. Variables with skewed distributions (e.g., Co and $\mathrm{Cr}$ levels) were compared using the Wilcoxon-Mann-Whitney test. Valuable correlations were calculated using Cox regression and Omnibus tests of model coefficients after adjusting for age, gender, acetabular cup, inclination, femur head size, metal ion (Co and $\mathrm{Cr}$ ) level, body mass index (BMI), and WOMAC index; these were used to make statistical comparisons of the revision rate between groups. The ROC curve was used to estimate the performance of cup inclination, $\mathrm{Cr}$ concentration, and $\mathrm{Co}$ concentration to revision surgery. The assumption of a valuable correlation was determined analytically for each model; if the interaction between the predictor and the $\log$ of the postoperative time was significant in the standard Cox regression model, a time-varying model was used. There were no missing data for the variables included in this study. All statistical analyses were performed using SPSS software.

\section{Results}

Of the 74 patients, there were $36(48.6 \%)$ males and 38 $(51.4 \%)$ females, with a mean age of $56.12 \pm 13.15$ years. The primary diseases for the initial THA were 33 (44.6\%) aseptic necrosis of femoral head (ANFH), 10 (13.5\%) osteoarthritis (OA), 16 (21.6\%) developmental dysplasia of the hip (DDH), 7 (9.5\%) traumatic arthritis, and $8(10.8 \%)$ other disease. The head size, cup size, and acetabular abduction angle of the prostheses were 45.12 $\pm 3.12 \mathrm{~mm}, 50.96 \pm 3.90 \mathrm{~mm}$, and $47.84 \pm 6.35^{\circ}$, respectively. The average follow-up time was 88.46 months with the range of 23 to 114 months (Table 1).

Within the follow-up time, there were 18 early failures (24.3\%) of the ASR XL MoM THAs that required revision surgery (Table 1). The mean overall survival time of the prostheses was 101.34 months (95\% CI 103.63110.67 months). All the prostheses were functioning well at the first 2-year follow-up and the revision rate increased over the next 8 years (Fig. 1).

Patients who received revision surgery had worse joint function with significantly lower HHS and WOMAC index than non-revision patients $(61.11 \pm 6.68$ vs $85.30 \pm$ 9.16, $p<0.001 ; 61.00 \pm 3.83$ vs $79.04 \pm 14.49, p<0.001$; respectively). The acetabular abduction angle of the revision group was significantly higher than that of the non-revision group $\left(51.54 \pm 3.30\right.$ vs $\left.46.64 \pm 6.65^{\circ}, p=0.004\right)$ while head size and cup size were comparable $(45.61 \pm 3.18$ vs $44.96 \pm 3.12 \mathrm{~mm}, p=0.448 ; 51.56 \pm 3.73$ vs $50.77 \pm$ $3.97 \mathrm{~mm}, p=0.460$; respectively). Further, we analyzed the serum $\mathrm{Co}$ and $\mathrm{Cr}$ concentration and found both $\mathrm{Co}$ and $\mathrm{Cr}$ concentrations were significantly
Table 1 Patients' characteristics

\begin{tabular}{ll}
\hline Characteristics & Patients (cases (\%)) \\
\hline Gender & $36(48.6)$ \\
Male & $38(51.4)$ \\
Female & $56.12 \pm 13.15$ \\
Age, years, mean \pm SD & $23.37 \pm 3.19$ \\
BMI (kg/m $\left.{ }^{2}\right)$, mean $\pm S D$ & \\
Primary disease & $33(44.6)$ \\
ANFH & $10(13.5)$ \\
Osteoarthritis & $16(21.6)$ \\
DDH & $7(9.5)$ \\
Traumatic arthritis & $8(10.8)$ \\
Else & \\
Revision surgery & $18(24.3)$ \\
Yes & $56(75.7)$ \\
No & $45.12 \pm 3.12$ \\
Head size (mm), mean $\pm S D$ & $50.96 \pm 3.90$ \\
Cup size (mm), mean $\pm S D$ & $47.84 \pm 6.35$ \\
Acetabular abduction angle $\left({ }^{\circ}\right)$, mean $\pm S D$ & $11.90 \pm 22.65$ \\
Serum Co concentration $(\mu g / L)$, mean $\pm S D$ & $107.12 \pm 30.16$ \\
Serum Cr concentration $(\mu g / L)$, mean $\pm S D$ & $88.46[23-114]$ \\
Fellow-up time (month), mean $[$ range] & \\
\hline BMI body mass & \\
\hline
\end{tabular}

$B M I$ body mass index, $A N F H$ aseptic necrosis of femoral head, $D D H$ developmental dysplasia of the hip, $S D$ standard deviation

higher in the revision group $(21.04 \pm 24.19$ vs $8.96 \pm$ $21.54 \mu \mathrm{g} / \mathrm{L}, \quad p=0.048 ; \quad 124.48 \pm 16.82$ vs $104.18 \pm$ $31.91 \mu \mathrm{g} / \mathrm{L}, p=0.012$; respectively), indicating a more severe metal abrasion (Table 2).

Higher acetabular abduction angle and serum $\mathrm{Cr}$ concentration were significantly relevant to lower HSS $\left(R^{2}=0.075, p=0.018 ; R^{2}=0.092, p=0.009\right.$; respectively $)$

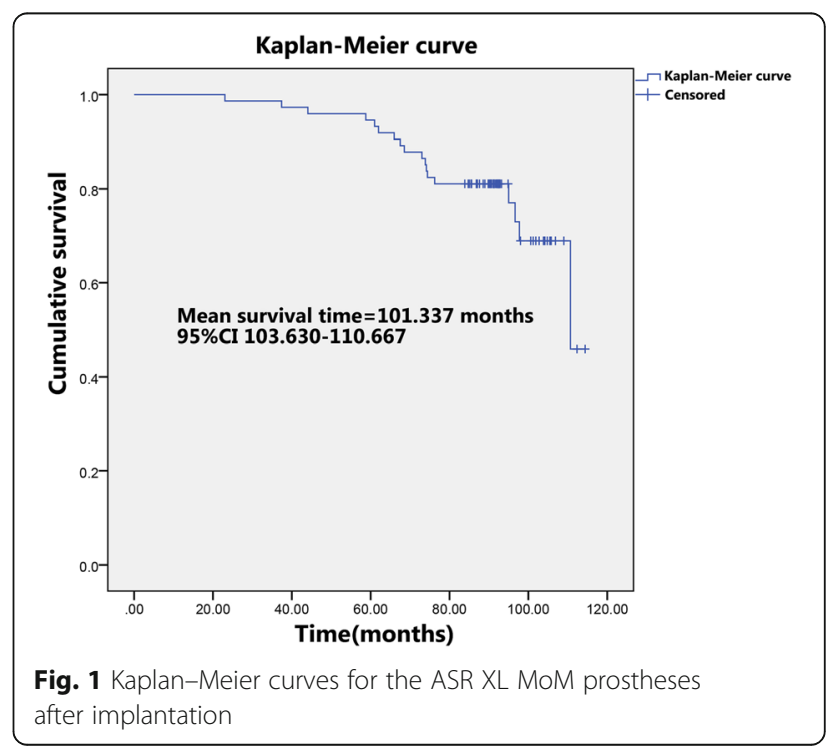


Table 2 Comparison between the revision patients and the non-revision patients

\begin{tabular}{|c|c|c|c|}
\hline & Non-revision $(N=56)$ & Revision $(N=18)$ & $P$ value \\
\hline Sex (Male:female) & $56(26: 30)$ & $18(10: 8)$ & 0.592 \\
\hline Age, years & $56.61 \pm 12.22$ & $54.61 \pm 16.01$ & 0.579 \\
\hline $\mathrm{BMl}, \mathrm{kg} / \mathrm{m}^{2}$ & $22.98 \pm 3.22$ & $24.57 \pm 2.84$ & 0.066 \\
\hline \multicolumn{4}{|l|}{ Primary disease } \\
\hline ANFH & 25 & 8 & \multirow[t]{5}{*}{0.365} \\
\hline Osteoarthritis & 9 & 1 & \\
\hline $\mathrm{DDH}$ & 13 & 3 & \\
\hline Traumatic arthritis & 5 & 2 & \\
\hline Else & 4 & 4 & \\
\hline Head size (mm) & $44.96 \pm 3.12$ & $45.61 \pm 3.18$ & 0.448 \\
\hline Cup size (mm) & $50.77 \pm 3.97$ & $51.56 \pm 3.73$ & 0.460 \\
\hline Acetabular abduction angle $\left(^{\circ}\right)$ & $46.64 \pm 6.65$ & $51.54 \pm 3.30$ & 0.004 \\
\hline Serum Co concentration $(\mu \mathrm{g} / \mathrm{L})$ & $8.96 \pm 21.54$ & $21.04 \pm 24.19$ & 0.048 \\
\hline Serum $\mathrm{Cr}$ concentration $(\mu \mathrm{g} / \mathrm{L})$ & $104.18 \pm 31.91$ & $124.48 \pm 16.82$ & 0.012 \\
\hline Harris Hip Score & $85.30 \pm 9.16$ & $61.11 \pm 6.68$ & $<0.001$ \\
\hline Western Ontario and McMaster Universities (WOMAC) index & $79.04 \pm 14.49$ & $61.00 \pm 3.83$ & $<0.001$ \\
\hline
\end{tabular}

$B M I$ body mass index, ANFH aseptic necrosis of femoral head, $D D H$ developmental dysplasia of the hip

and WOMAC index $\left(R^{2}=0.048, p=0.018 ; R^{2}=0.063\right.$, $p=0.031$; respectively) (Fig. $2 \mathrm{a}, \mathrm{b}, \mathrm{d}$, and e). Higher serum Co concentration was also significantly relevant to lower HSS $\left(R^{2}=0.055, p=0.043\right)$ but not to WOMAC index $\left(R^{2}=0.020, p=0.235\right)$ (Fig. 2c, f). These data revealed that higher acetabular abduction angle and serum $\mathrm{Cr}$ and Co concentration may be risk factors of bad joint function, early prostheses failure, and subsequent revision surgery. To confirm this hypothesis, ROC curve analysis was applied to categorize the optimal cutoff values of acetabular abduction angle and serum $\mathrm{Cr}$ and $\mathrm{Co}$ concentration for revision surgery, which were settled as $47.80^{\circ}, 98.44 \mu \mathrm{g} / \mathrm{L}$, and $6.95 \mu \mathrm{g} / \mathrm{L}$, respectively (Fig. 3a-c). Based on this setting, we classified the patients into groups of "high acetabular abduction angle $\left(>47.80^{\circ}\right)$ ", "high serum $\mathrm{Cr}$ concentration $(>98.44 \mu \mathrm{g} / \mathrm{L})$ " and "high serum Co concentration $(>6.95 \mu \mathrm{g} / \mathrm{L})$ ". The Kaplan-Meier curves were then carried out to compare the overall survival (OS) of the prostheses between the higher and lower group in each parameter above. The results demonstrated that the OS with high acetabular abduction angle ( $\mathrm{HR}=70.145,95 \%$ CI $1.558-3158.213, p=0.029)$, high serum $\mathrm{Cr}$ concentration $(\mathrm{HR}=58.956,95 \% \mathrm{CI}$ 1.294-2685.203, $p=0.036$ ), and high serum Co concentration $(\mathrm{HR}=179.511,95 \%$ CI 2.360-13656.941, $p=0.019)$ decreased significantly than the lower groups (Fig. 3d-f).

In the revision procedures, cystic changes were noted in nearly all cases (Fig. 4a-d), 8 of 18 cases exhibited pseudotumor formation. Mild metal staining was noted in gross soft tissues. Aside from the two cases of gross loosening of the acetabular component, cups appeared mechanically stable; however, an osteolytic membrane was encountered around the outer rim in all cases (Fig. 4g). Less than $25 \%$ in-growth was noted on the explanted cups. Significant stress shielding of the retroacetabular bone was also noted. At 6 weeks after revision, all patients reported marked improvement in preoperative pain. At 1 year after revision, all patients were asymptomatic.

\section{Discussion}

To investigate the relationships among acetabular cup inclination, head size, serum metal ion levels, and revision rate, we performed metal-on-metal THA in a consecutive series of patients. We also assessed self-reported hip function. Despite the theoretical advantages of increased head size and low-bearing surface wear, our senior surgeon handled THA with the DePuy ASR XL and had a $24.3 \%$ incidence of early revision.

Although MoM articulations possess numerous theoretical advantages in implant design, concerning revision rates have been reported in many MoM implant systems. The surgeon notification provided by DePuy in conjunction with the August 2010 recall of the device noted a 13\% revision rate for the ASR XL MoM THA [12]. The revision rate, regardless of reason, reported in different studies of the ASR Hip System stratified by time from index surgery was $28.0 \%$ during the follow-up period of 6 to 7 years. Dastane et al. reported a 6-year failure rate of $25 \%$ for Articular Surface Replacement (ASR) resurfacing (DePuy, Leeds, UK) and one of $48.8 \%$ for 

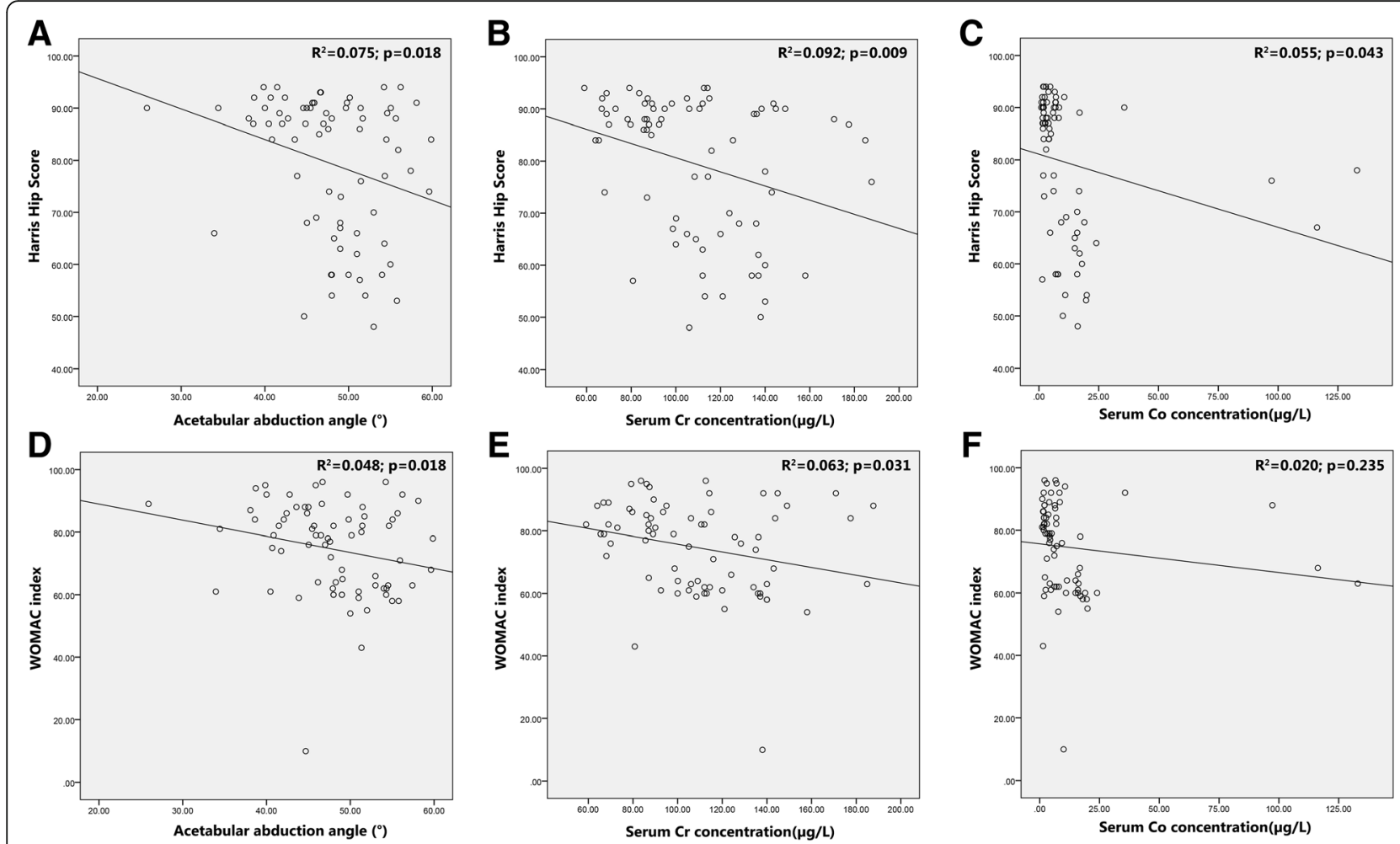

Fig. 2 a-f Scatter diagram and correlation analysis of the acetabular abduction angle, serum Co and Cr concentration with HSS and WOMAC index. HSS: Harris Hip Score. WOMAC index: Western Ontario and McMaster Universities index

ASR THA. The revision rate observed at our institute is close to the median value reported in their series, and our results are similar to previously reported studies that used the same acetabular construct.

The association between component orientation and bearing surface wear $[13,14]$, as well as blood metal ion concentration, is well documented. We observed an increased risk for elevated revision rate related to high cup acetabular abduction angle in the ASR THA group. Cup inclination was identified as a statistically significant factor in determining the revision rate in our patient cohort. Similarly, in three other studies, the suboptimal acetabular abduction angle was associated with a higher revision rate for ALTR or an increased early revision rate [15-17].

The issue of taper debris is associated with greater tissue damage than equivalent doses from the bearing surface [18], that is believed to be the main reason for higher metal ion concentrations in THAs [19], as the rates of bearing surface wear in MoM THAs and resurfacings are similar [20]. Corrosion is more often seen at the titanium (Ti)-CoCr interface; the Biomet ReCaps (Biomet Manufacturing, LLC in Warsaw) has a Ti-Tiinterface, which results in a lower Co release in Biomet MoM THAs using a Ti sleeve [21].

High wear rate is the major determinant of failure of large MoM hip implants, and edge loading has been identified as the most important predictor [22]. A large femoral head size in ASR XL THA is believed to be a risk factor for ALTR and an increased revision rate due to trunnionosis. In our study, both serum $\mathrm{Co}$ and $\mathrm{Cr}$ concentrations were not relevant to cup size $(p=0.205, p=0.701$, respectively) and head size ( $p=0.667, p=0.476$, respectively). However, serum $\mathrm{Cr}$ concentration was proved to be correlated with the acetabular abduction angle $(p=0.014)$ in our study, in accordance with the findings of previous studies that found higher blood metal ion levels with decreased/increased abduction angles of the acetabular component [23, 24]. High acetabular abduction angle may lead to abnormal edge loading, resulting in high serum metal ion concentration.

Higher blood metal ion values clearly correlated with a higher revision rate, ALTR prevalence, and raised blood lymphocyte levels $[25,26]$. With increasing concerns regarding the high failure rate of large-head MoM THAs, it is important to identify a safe upper limit for femoral head size in MoM THA. Concentrations of $5 \mu \mathrm{g} / \mathrm{L}$ and $7 \mu \mathrm{g} / \mathrm{L}$ have been used as thresholds for $\mathrm{Co}$ and $\mathrm{Cr}$ levels, respectively. We detected much higher concentrations of serum metal ions ( $\mathrm{Co}$ and $\mathrm{Cr}$ ), with the mean levels reaching $11.90 \mu \mathrm{g} / \mathrm{L}$ and $107.12 \mu \mathrm{g} / \mathrm{L}$, respectively, especially in the revised group (Co and $\mathrm{Cr}$ levels were $21.04 \mu \mathrm{g} / \mathrm{L}$ and $124.48 \mu \mathrm{g} / \mathrm{L}$, respectively). In our cohort, 

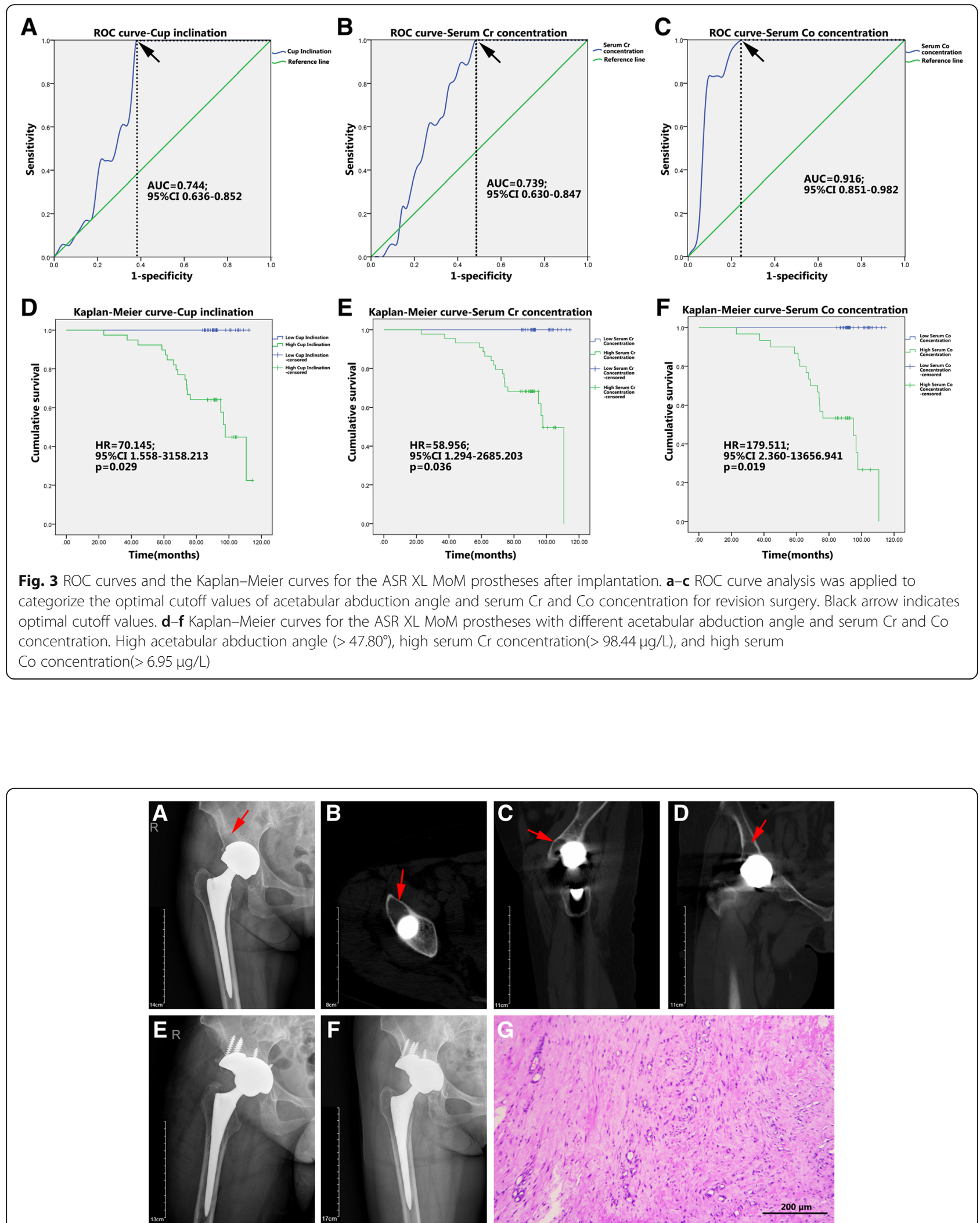

Fig. 4 A typical revised case of the ASR XL MoM prostheses with cystic changes in periprosthetic bone. X-ray (a), cross section (b), sagittal section (c), and coronal section (d) of CT scan. Red arrow indicates bone cyst formation. X-ray images of 1 week (e) and 1 year (f) after revision surgery. HE staining of the periprosthetic soft tissue exhibited dense fibrous tissue with granuloma formation (g). Scale bar $=200 \mu \mathrm{m}$ 
a $6.95 \mu \mathrm{g} / \mathrm{L}$ cutoff of Co level and a $98.44 \mu \mathrm{g} / \mathrm{L}$ cutoff of $\mathrm{Cr}$ levels were made based on ROC curve analysis, with $78.6 \%$ and $53.6 \%$ specificity, respectively, and both $100 \%$ sensitivity. The Kaplan-Meier curves further demonstrated that patients with high Co level $(>6.95 \mu \mathrm{g} / \mathrm{L})$ or high $\mathrm{Cr}$ level $(>98.44 \mu \mathrm{g} / \mathrm{L})$ exhibited significantly higher revision rate and shorter prostheses survival time. Our data re-emphasized the predictive value of serum Co and $\mathrm{Cr}$ level for early failure and revision surgery in patients with ASR XL MoM THAs.

Although we found a pseudotumor prevalence of $44.44 \%$ ( 8 in 18) in our study, we did not determine the potential correlation between the presence of a pseudotumor and other risk factors, including elevated metal ion levels and/or image demonstration after MoM THA. Hailer et al. [27] characterized the risk factors of pseudotumor formation; apart from Co level, which was discussed earlier, they found an inverse relationship between implant size and the formation of pseudotumors. Pseudotumors are a common complication of MoM arthroplasties, and elevated metal ion concentrations in the blood are also a common finding after such procedures [9, 28]. However, Bayley [29] indicated no association between the presence of pseudotumors and the potential risk factors analyzed herein, including elevated metal ion levels.

There are several limitations to our study. First, this was a retrospective, randomized study. The retrospective methodology limits data collection options; indeed, 26 hips were lost to follow-up during the study. Moreover, the retrospective used in this study design lends itself to several biases, including selection and recall. A second limitation is that, during the revision procedure, we observed the formation of a pseudotumor periprosthetic but did not collect any objective images, such as ultrasonography or the more sensitive metal artifact reduction sequence magnetic resonance imaging (MARS MRI). These could have clarified the prevalence of pseudotumors preoperatively and, thus, allowed us to better assess the formation of pseudotumors. A third limitation is the relatively small sample size. Between July 2006 and January 2010, our institution performed 3,000 THAs; however, only 200 hips received the ASR XL MoM THA (100 hips complied with the follow-up visits). In China, even more than one agency had done so many THAs, our follow-up data may not delegate for the integrity. Additionally, we did not evaluate the effect of the specific stem and cup combinations due to the large variety of stems used. Differences in the wear properties and metal ion release between taper designs have been described elsewhere [16]. Limiting the analysis to only bearing surface brands may oversimplify the results.

Thus, we advocate that patients with DePuy ASR XL implants be followed up more closely than patients with other implants, especially when symptomatic. Owing to the unusually high failure rate, poor early results with a relatively new implant design highlight the need for a national joint registry; indeed, an implant such as this one, with a poorer-than-expected survivorship, could have been more quickly identified and removed from the market. Further long-term, comparative studies of MoM and alternative bearing surfaces remain a priority for future research.

\section{Conclusions}

Evaluation of the DePuy ASR XL articulation demonstrated increased rates of revision following a longer follow-up period. High acetabular abduction angle and serum $\mathrm{Cr}$ and Co concentration correlated with worse clinical outcomes and high revision rate. Therefore, we advocate that patients with DePuy ASR XL implants be followed up more closely than those with other implants, especially with high acetabular abduction angle and serum $\mathrm{Cr}$ or Co concentration.

\section{Abbreviations}

ASR: Articular surface replacement; HHS: Harris Hip Score; MOM: Metal-onmetal; ROM: Range of motion; THA: Total hip arthroplasty; WOMAC: Western Ontario and McMaster Universities

\section{Acknowledgements \\ I would like to express my gratitude to all those who have helped me during the writing of this thesis. I gratefully acknowledge the help of my supervisor Professor Wu Lidong. Also, I would like to thank Mr. Ran Jisheng and Mr. Chen Weiping, who kindly gave me a hand when I was making the questionnaire among the patients. Last but not the least, my gratitude also extends to my family who have been assisting, supporting, and caring for me all of my life.}

\section{Funding}

This study was supported by Taizhou Science and Technology Bureau Grant (15yw05).

\section{Availability of data and materials \\ There is no any other supporting data.}

\section{Authors' contributions}

GJ and LW conceived and designed the study. GJ, JR, and WC performed the experiments. GJ and LW wrote the paper. GJ, LW, YX, and JB reviewed and edited the manuscript. All authors read and approved the final manuscript.

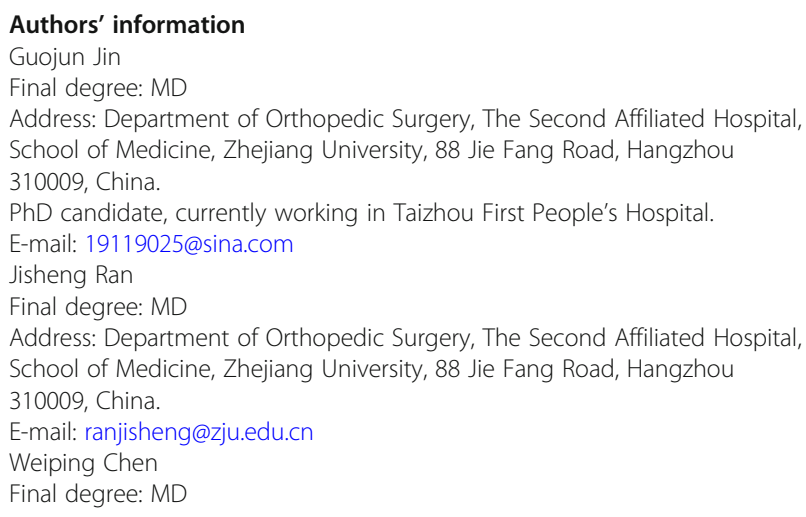


Address: Department of Orthopedic Surgery, The Second Affiliated Hospital, School of Medicine, Zhejiang University, 88 Jie Fang Road, Hangzhou 310009, China

E-mail: cwpstks@126.com

Yan Xiong

Final degree: MD

Address: Department of Orthopedic Surgery, The Second Affiliated Hospital, School of Medicine, Zhejiang University, 88 Jie Fang Road, Hangzhou 310009, China.

E-mail: xiongyanbear@zju.edu.cn

Jiapeng Bao

Final degree: MD

Address: Department of Orthopedic Surgery, The Second Affiliated Hospital,

School of Medicine, Zhejiang University, 88 Jie Fang Road, Hangzhou

310009, China.

E-mail: baojiapeng2007@aliyun.com

\section{Ethics approval and consent to participate}

Prior to the initiation of this study, approval was obtained from the Second Affiliated Hospital, School of Medicine, Zhejiang University ethics committee "The prognosis of hip arthroplasty using metal-to-metal prosthesis" (NO. 2017043), and each patient provided informed consent.

\section{Consent for publication}

My manuscript does not contain any individual persons data. Not applicable. The co-authors consented to the publication of this is article.

\section{Competing interests}

The authors declare that they have no competing interests.

\section{Publisher's Note}

Springer Nature remains neutral with regard to jurisdictional claims in published maps and institutional affiliations.

\section{Author details}

'Department of Orthopedics, Taizhou First People's Hospital, 218th Hengjie Road, Taizhou 318020, China. ${ }^{2}$ Department of Orthopedic Surgery, The Second Affiliated Hospital, Zhejiang University School of Medicine, 88th Jie Fang Road, Hangzhou 310009, China.

\section{Received: 21 June 2018 Accepted: 29 April 2019}

Published online: 24 May 2019

\section{References}

1. Amstutz HC, Campbell P, Kossovsky N, Clarke IC. Mechanism and clinical significance of wear debris-induced osteolysis. Clin Orthop Relat Res. 1992 7-18.

2. Cuckler JM. The rationale for metal-on-metal total hip arthroplasty. Clin Orthop Relat Res. 2005:441:132-6.

3. Dastane MR, Long WT, Wan Z, Chao L, Dorr LD. Metal-on-metal hip arthroplasty does equally well in osteonecrosis and osteoarthritis. Clin Orthop Relat Res. 2008;466:1148-53.

4. Cuckler JM, Moore KD, Lombardi AV Jr, McPherson E, Emerson R. Large versus small femoral heads in metal-on-metal total hip arthroplasty. J Arthroplasty. 2004;19:41-4.

5. Penny JO, Ding M, Varmarken JE, Ovesen O, Overgaard S. Early micromovement of the Articular Surface Replacement (ASR) femoral component: two-year radiostereometry results. J Bone Joint Surg Br. 2012; 94:1344-50.

6. Daniel J, Ziaee H, Pradhan C, McMinn DJ. Six-year results of a prospective study of metal ion levels in young patients with metal-on-metal hip resurfacings. J Bone Joint Surg Br. 2009;91:176-9.

7. Langton DJ, Sidaginamale RP, Joyce TJ, Natu S, Blain P, Jefferson RD, Rushton S, Nargol AV. The clinical implications of elevated blood metal ion concentrations in asymptomatic patients with MoM hip resurfacings: a cohort study. BMJ open. 2013;3.

8. Langton DJ, Sprowson AP, Joyce TJ, Reed M, Carluke I, Partington P, Nargol AV. Blood metal ion concentrations after hip resurfacing arthroplasty: a comparative study of articular surface replacement and Birmingham Hip Resurfacing arthroplasties. J Bone Joint Surg Br. 2009;91:1287-95.
9. Bosker BH, Ettema HB, Boomsma MF, Kollen BJ, Maas M, Verheyen CC. High incidence of pseudotumour formation after large-diameter metal-on-metal total hip replacement: a prospective cohort study. J Bone Joint Surg Br. 2012:94:755-61.

10. Hart AJ, Satchithananda K, Liddle AD, Sabah SA, McRobbie D, Henckel J, Cobb JP, Skinner JA, Mitchell AW. Pseudotumors in association with wellfunctioning metal-on-metal hip prostheses: a case-control study using three-dimensional computed tomography and magnetic resonance imaging. J Bone Joint Surg Am. 2012;94:317-25.

11. Pei KL, Kinniburgh DW, Butlin L, Faris P, Lee D, Marshall DA, Oliver MC, Parker R, Powell JN, Railton P, Smith J. An ORS-ICP-MS method for monitoring trace levels of cobalt and chromium in whole blood samples from hip arthroplasty patients with metal-on-metal prostheses. Clin Biochem. 2012;45:806-10.

12. Laaksonen I, Donahue GS, Madanat R, Makela KT, Malchau H. Outcomes of the recalled articular surface replacement metal-on-metal hip implant system: a systematic review. J Arthroplasty. 2017;32:341-6.

13. Malek IA, King A, Sharma H, Malek S, Lyons K, Jones S, John A. The sensitivity, specificity and predictive values of raised plasma metal ion levels in the diagnosis of adverse reaction to metal debris in symptomatic patients with a metal-on-metal arthroplasty of the hip. J Bone Joint Surg Br. 2012;94:1045-50.

14. Matthies AK, Henckel J, Cro S, Suarez A, Noble PC, Skinner J, Hart AJ. Predicting wear and blood metal ion levels in metal-on-metal hip resurfacing. J Orthop Res. 2014;32:167-74.

15. Bernstein M, Desy NM, Petit A, Zukor DJ, Huk OL, Antoniou J. Long-term follow-up and metal ion trend of patients with metal-on-metal total hip arthroplasty. Int Orthop. 2012;36:1807-12.

16. Cip J, von Strempel A, Bach C, Luegmair M, Benesch T, Martin A. Implication of femoral stem on performance of articular surface replacement (ASR) XL total hip arthroplasty. J Arthroplasty. 2014;29:2127-35.

17. Langton DJ, Jameson SS, Joyce TJ, Hallab NJ, Natu S, Nargol AV. Early failure of metal-on-metal bearings in hip resurfacing and large-diameter total hip replacement: a consequence of excess wear. J Bone Joint Surg Br. 2010;92:38-46.

18. Sidaginamale RP, Joyce TJ, Bowsher JG, Lord JK, Avery PJ, Natu S, Nargol AV Langton DJ. The clinical implications of metal debris release from the taper junctions and bearing surfaces of metal-on-metal hip arthroplasty: joint fluid and blood metal ion concentrations. Bone Joint J. 2016;98-b:925-33.

19. Langton DJ, Joyce TJ, Jameson SS, Lord J, Van Orsouw M, Holland JP, Nargol AV, De Smet KA. Adverse reaction to metal debris following hip resurfacing: the influence of component type, orientation and volumetric wear. J Bone Joint Surg Br. 2011;93:164-71.

20. Matthies A, Underwood R, Cann P, Ilo K, Nawaz Z, Skinner J, Hart AJ. Retrieval analysis of 240 metal-on-metal hip components, comparing modular total hip replacement with hip resurfacing. J Bone Joint Surg Br. 2011:93:307-14.

21. Lavigne M, Belzile EL, Roy A, Morin F, Amzica T, Vendittoli PA. Comparison of whole-blood metal ion levels in four types of metal-on-metal largediameter femoral head total hip arthroplasty: the potential influence of the adapter sleeve. J Bone Joint Surg Am. 2011;93(Suppl 2):128-36.

22. Hart AJ, Muirhead-Allwood S, Porter M, Matthies A, llo K, Maggiore $P$, Underwood R, Cann P, Cobb J, Skinner JA. Which factors determine the wear rate of large-diameter metal-on-metal hip replacements? Multivariate analysis of two hundred and seventy-six components. J Bone Joint Surg Am. 2013:95:678-85.

23. De Haan R, Pattyn C, Gill HS, Murray DW, Campbell PA, De Smet K. Correlation between inclination of the acetabular component and metal ion levels in metal-on-metal hip resurfacing replacement. J Bone Joint Surg Br. 2008;90:1291-7.

24. Hart AJ, Skinner JA, Henckel J, Sampson B, Gordon F. Insufficient acetabular version increases blood metal ion levels after metal-on-metal hip resurfacing. Clin Orthop Relat Res. 2011;469:2590-7.

25. Chang EY, McAnally JL, Van Horne JR, Van Horne JG, Wolfson T, Gamst A, Chung CB. Relationship of plasma metal ions and clinical and imaging findings in patients with ASR XL metal-on-metal total hip replacements. J Bone Joint Surg Am. 2013;95:2015-20.

26. Cip J, Bach C, Widemschek M, Luegmair M, Martin A. Revision of articular surface replacement (ASR) total hip arthroplasty: correlation of perioperative data and early post-revision outcome results. J Arthroplasty. 2015;30:1607-17. 
27. Hailer NP, Bengtsson M, Lundberg C. High metal ion levels after use of the ASRTM device correlate with development of pseudotumors and T cell activation []]. Clin Orthop Relat Res. 2014;472(3):953-61. https://doi.org/10. 1007/s1 1999-013-3307-x.

28. Pandit H, Glyn-Jones S, McLardy-Smith P, Gundle R, Whitwell D, Gibbons CL, Ostlere S, Athanasou N, Gill HS, Murray DW. Pseudotumours associated with metal-on-metal hip resurfacings. J Bone Joint Surg Br. 2008;90:847-51.

29. Bayley N, Khan H, Grosso P, Hupel T, Stevens D, Snider M, Schemitsch E, Kuzyk P. What are the predictors and prevalence of pseudotumor and elevated metal ions after large-diameter metal-on-metal THA? Clin Orthop Relat Res. 2015:473:477-84.

Ready to submit your research? Choose BMC and benefit from:

- fast, convenient online submission

- thorough peer review by experienced researchers in your field

- rapid publication on acceptance

- support for research data, including large and complex data types

- gold Open Access which fosters wider collaboration and increased citations

- maximum visibility for your research: over $100 \mathrm{M}$ website views per year

At BMC, research is always in progress.

Learn more biomedcentral.com/submissions 